\title{
Expression of insulin receptor on clonal pancreatic alpha cells and its possible role for insulin-stimulated negative regulation of glucagon secretion
}

\author{
K. Kisanuki, H. Kishikawa, E. Araki, T. Shirotani, M. Uehara, S. Isami, S. Ura, H.Jinnouchi, N. Miyamura, M. Shichiri \\ Department of Metabolic Medicine, Kumamoto University School of Medicine, Kumamoto, Japan
}

\begin{abstract}
Summary In pancreatic alpha cells, the existence and function of the insulin receptor has not yet been fully established. In this study, to confirm the expression of functional insulin receptors in pancreatic alpha cells, we performed: 1) insulin receptor binding assay, 2) Northern blot analysis and RT-PCR (reverse transcription-polymerase chain reaction) amplification of insulin receptor mRNA, 3) immunocytochemical staining, 4) biosynthetic labelling of insulin receptor protein using $\left[{ }^{35} \mathrm{~S}\right]$ methionine, 5) analysis of insulinstimulated autophosphorylation of the insulin receptor in glucagon secreting cell lines, In-R1-G9 and $\alpha \mathrm{TC}$ clone 6 cells. Glucagon secretion decreased with the addition of insulin in both cells. The receptor binding studies using [ ${ }^{125} \mathrm{I}-\mathrm{Ty}$ r-A14] insulin revealed that both cells possessed a significant number of insulin receptors (In-R1-G9: $\mathrm{K}_{1}=2.1 \times 10^{9} \mathrm{~mol} / \mathrm{1}^{-1}$, $\mathrm{K}_{2}=6.2 \times 10^{7} \mathrm{~mol} / \mathrm{l}^{-1}, \mathrm{R}_{1}=0.27 \times 10^{4}, \mathrm{R}_{2}=1.86 \times 10^{4}$ sites/cell; $\quad \alpha \mathrm{TC}$ clone $6: \mathrm{K}_{1}=2.1 \times 10^{9} \mathrm{~mol} / \mathrm{l}^{-1}$,
\end{abstract}

$\mathrm{K}_{2}=7.3 \times 10^{7} \mathrm{~mol} / \mathrm{l}^{-1}, \mathrm{R}_{1}=0.27 \times 10^{4}, \mathrm{R}_{2}=1.95 \times 10^{4}$ sites/cell). Northern blot analysis as well as RT-PCR amplification showed the mRNA specific for insulin receptor in both cells. By immunocytochemical staining using anti-insulin receptor $\alpha$-subunit antibody, positive immunostaining for insulin receptor was observed in both cells. [ ${ }^{35}$ S]Methionine labelling of both cells followed by immunoprecipitation using anti-insulin receptor antibody showed the correct size of the insulin receptor protein. The insulin receptor expressed in these cells underwent autophosphorylation by insulin stimulation. It is concluded that functional insulin receptors are properly expressed in In-R1-G9 and $\alpha$ TC clone 6 cells.

Key words Pancreatic alpha cell, In-R1-G9, $\alpha \mathrm{TC}$ clone 6 , insulin receptor, glucagon secretion [Diabetologia (1995) 38: 422-429]
It is well-known that optimal administration of insulin normalizes a paradoxical rise, after an oral glucose load and an exaggerated rise during intravenous arginine infusion, in plasma glucagon secretion in either hypoinsulinaemic or hyperinsulinaemic diabetic pa-

Received: 13 July 1994 and in revised form: 18 October 1994

Corresponding author: Dr. K. Kisanuki, Department of Metabolic Medicine, Kumamoto University School of Medicine, 11-1 Honjo, Kumamoto, 860, Japan

Abbreviations: RT-PCR, Reverse transcriptase-polymerase chain reaction; FBS, fetal bovine serum; DMEM, Dulbecco's modified Eagle's medium; BSA, bovine serum albumin; PBS, phosphate buffered saline; SDS, sodium dodecyl sulphate; SSC, saline sodium citrate. tients [1-4]. According to these studies, negative regulation of glucagon secretion by insulin has been proposed as the reason. Most, if not all, actions of insulin, have been shown to be mediated by the insulin receptor through its tyrosine kinase $[5,6]$. Therefore, to account for the negative regulation of glucagon secretion by insulin, the existence of insulin receptors on pancreatic alpha cells has been proposed and studied by several investigators. Patel [7] demonstrated using the electron microscope that autoradiographic grains associated with $\left.{ }^{125} \mathrm{I}\right]$ insulin were found on alpha cells in isolated rat islets after $\left.{ }^{125} \mathrm{I}\right]$ insulin treatment. However, Van Schravendijk et al. [8] studied the existence of insulin receptors using the receptor binding assay technique, but did not demonstrate significant binding of insulin to purified pancreatic alpha cells. Thus, 
the existence of insulin receptors has not yet been demonstrated on either purified pancreatic alpha cells or clonal pancreatic alpha-cell lines.

In this report, to confirm the expression of functional insulin receptors on pancreatic alpha cells, we performed biochemical, immunocytochemical, and molecular biological methods with two independent established clonal pancreatic alpha-cell lines; In-R1G9 [9] and $\alpha$ TC clone 6 ( $\alpha$ TC-6) cells [10]. We clearly demonstrate here the expression of insulin receptor mRNA and protein, and autophosphorylation of the insulin receptor by insulin stimulation in these clonal cell lines. Our results suggest that insulin may modulate glucagon secretion by the pancreatic alpha cell through its cell surface insulin receptor.

\section{Materials and methods}

Materials. $\quad \mathrm{N}$-(2-hydroxyethyl)-piperazine-N'-2-ethanesulphonic acid (HEPES), 2-amino-2-(hydroxymethyl)-1,3propanediol (Tris), 3-amino-9-ethylcalbazol (AEC), dimethylsulphoxide (DMSO), Triton X-100, polyoxyethylenesorbitan monolaurate (Tween 20), sodium pyrophosphate, phenylmethyl sulphonyl fluoride (PMSF), sodium orthovanadate, sodium fluoride, Bacitracin, dithiothreitol (DTT), porcine insulin and DNase (RNase-free) were obtained from Sigma ( $\mathrm{St}$ Louis, Mo., USA). $\left[\alpha^{-32} \mathrm{P}\right] \mathrm{dCTP},\left[{ }^{35} \mathrm{~S}\right]$ methionine, $\left[\gamma{ }^{32} \mathrm{P}\right] \mathrm{ATP}$, and $\left[{ }^{125} \mathrm{I}\right.$-Tyr-A14]insulin were supplied by NEN-Dupont (Wilmington, Del., USA). RPMI-1640 medium and Dulbecco's modified Eagle's medium (DMEM) were purchased from Gibco (Grand Island, N. Y., USA). Oligotex and ampli Taq DNA polymerase, nitrocellulose membrane, RNase inhibitor, Avian Moloney virus-reverse transcriptase, Gene Clean kit, and Sequenase version 2.0 DNA sequencing kit were purchased from Takara Shuzo (Kyoto, Japan), Schleicher \& Schuell (Dassel, Germany), Promega (Madison, Wis., USA), Seikagaku Corporation (Tokyo, Japan), Bio 101 Incorporated (La Jolla, Calif., USA), and United States Biochemical Company (Cleveland, Ohio, USA), respectively. Anti-insulin receptor $\beta$-subunit monoclonal antibody (Ab-3), anti-insulin receptor $\alpha$-subunit polyclonal antibody, anti-rabbit $\mathrm{Ig}$ horseradish peroxidase linked $\mathrm{F}\left(\mathrm{ab}^{\prime}\right)_{2}$ fragment and Protein G-Sepharose 4B were from Oncogene Science (Manhasset, N.Y., USA), UBI (Lake Placid, N. Y., USA), Amersham Corporation (Arlington Heights, Ill., USA), Zymed Laboratories Incorporated (South San Francisco, Calif., USA), respectively. Lab-Tek chamber slide and Aquatex were purchased from Nunc Incorporated (Naperville, Ill., USA) and Merck (Frankfurt, Germany), respectively.

Cell culture. In-R1-G9 cells cloned from hamster insulinoma (In-111-R1) [9] (a gift from Takaki) were grown in RPMI1640 medium supplemented with $5 \%$ fetal bovine serum. (FBS), $100 \mathrm{mg} / \mathrm{l}$ streptomycin and $75 \mathrm{mg} / \mathrm{l}$ penicillin sulphate under $5 \% \mathrm{CO}_{2}$ and $95 \%$ air at $37^{\circ} \mathrm{C}$. $\alpha \mathrm{TC}-6$ cells, subcloned from the $\alpha \mathrm{TC}-1$ line derived from a transgenic mouse adenoma expressing the simian virus (SV) 40 large T-antigen under the control of rat preproglucagon promoter $[10,11]$ (a gift from Hamaguchi), were grown in DMEM with $25 \mathrm{mmol} / \mathrm{lglu}$ cose, $10 \%$ FBS, $100 \mathrm{mg} / 1$ streptomycin and $75 \mathrm{mg} / 1$ penicillin sulphate under $5 \% \mathrm{CO}_{2}$ and $95 \%$ air at $37^{\circ} \mathrm{C}$.

Effect of insulin on glucagon secretion. One million In-R1-G9 or $\alpha$ TC- 6 cells were plated on $60-\mathrm{mm}$ dishes and cultured over- night to obtain a cell monolayer. Culture media were switched from RPMI- 1640 medium with $5 \%$ FBS to RPMI-1640 medium with $0.5 \%$ bovine serum albumin (BSA) for In-R1-G9 cells and from DMEM (25 mmol/l glucose) with $10 \% \mathrm{FBS}$ to DMEM ( $25 \mathrm{mmol} / \mathrm{l}$ glucose) with $0.5 \% \mathrm{BSA}$ for $\alpha$ TC-6 cells, respectively, at $1 \mathrm{~h}$ before the addition of insulin. After washing twice, cells were incubated for $2 \mathrm{~h}$ in each medium with or without various concentrations of porcine insulin. Then $1 \times 10^{6}$ In-R1-G9 and $\alpha$ TC- 6 cells were incubated in RPMI1640 medium with $0.5 \%$ BSA and DMEM (25 mmol/1 glucose) with $0.5 \%$ BSA, respectively, with or without $10^{-8} \mathrm{~mol} / 1$ porcine insulin for $2,6,12$ and $24 \mathrm{~h}$. Culture media were kept frozen until glucagon assay.

Insulin receptor binding assay. In-R1-G9 or $\alpha$ TC- 6 cells $\left(1 \times 10^{5}\right.$, respectively) were plated in 12-well culture dishes. They were washed twice with binding buffer (100 mmol/l HEPES $\mathrm{pH} 7.5$ containing $120 \mathrm{mmol} / \mathrm{l} \mathrm{NaCl}, 1.2 \mathrm{mmol} / 1 \mathrm{MgSO}_{4}$, $1 \mathrm{mmol} / \mathrm{l} \mathrm{EDTA}, 15 \mathrm{mmol} / \mathrm{l}$ sodium acetate, $10 \mathrm{mmol} / \mathrm{lglu}-$ cose and $1 \% \mathrm{BSA}$ ) and incubated with [ ${ }^{125} \mathrm{I}$-Tyr-A14]insulin $(30 \mathrm{pmol} / \mathrm{l})$ and various concentrations of unlabelled insulin for $16 \mathrm{~h}$ at $4{ }^{\circ} \mathrm{C}$. After incubation, cells were washed three times with $1 \mathrm{ml}$ cold phosphate-buffered saline (PBS) and solubilized with $500 \mu 10.1 \mathrm{~mol} / 1 \mathrm{NaOH}$ for $15 \mathrm{~min}$ at $37^{\circ} \mathrm{C}$. The radioactivity of the cell lysates was then measured by gamma counter. The data from binding assays were analysed using displacement curves and Scatchard plots [12], and affinity constants and binding sites were calculated by the method of Thakur et al. [13] using a computer program based on the two-site model proposed by Rosenthal [14].

Northern blot analysis. Total RNAs were isolated from In-R1G9 or $\alpha$ TC- 6 cells and hamster or mouse tissues (liver and kidney) using the guanidium thiocyanate- $\mathrm{CsCl}$ technique [15]. Poly (A) ${ }^{+}$RNAs were then extracted from total RNAs by Oligotex, according to the manufacturer's instructions. Poly(A) ${ }^{+}$RNA $(10 \mu \mathrm{g})$ from liver or kidney cells, or both cells, were denatured with formaldehyde, separated by $1.0 \%$ agarose gel electrophoresis, and transferred to nitrocellulose membranes. Hybridization of the filters with $\left[\alpha_{-}^{32} \mathrm{P}\right] \mathrm{dCTP}$ random-priming labelled human insulin receptor cDNA $(4.4 \mathrm{~kb})$ [16] was carried out in $50 \%$ formamide, $5 \times \mathrm{SSC}$ $(1 \times \mathrm{SSC}=150 \mathrm{mmol} / \mathrm{l} \mathrm{NaCl}, 15 \mathrm{mmol} / 1$ sodium citrate $)$, $5 \times$ Denhardt's solution $(1 \times$ Denhardt's solution $=0.02 \%$ polyvinyl pyrrolidone, $0.02 \%$ Ficoll, $0.02 \% \mathrm{BSA}$ ), $50 \mathrm{mmol} / 1$ sodium phosphate buffer $\mathrm{pH} 7.0,0.1 \%$ sodium dodecyl sulphate (SDS) and $100 \mu \mathrm{g} / \mathrm{ml}$ salmon sperm DNA overnight at $42^{\circ} \mathrm{C}$ with specific activity of $1 \times 10^{6} \mathrm{cpm} / \mathrm{ml}$. The filters were washed in $1 \times \mathrm{SSC}$ with $0.2 \% \mathrm{SDS}$ and $0.5 \times \mathrm{SSC}$ with $0.2 \%$ $\mathrm{SDS}$ at $60^{\circ} \mathrm{C}$ for $30 \mathrm{~min}$ and subjected to autoradiography.

Reverse transcription-polymerase chain reaction (RT-PCR) analysis. After treatment with DNase (RNase-free) at $37^{\circ} \mathrm{C}$ for $60 \mathrm{~min}$ in DNase buffer $(0.1 \mathrm{~mol} / 1$ sodium acetate, $5 \mathrm{mmol} /$ $1 \mathrm{MnCl}_{2}$ ), $3 \mu \mathrm{g}$ of total RNA from In-R1-G9 or $\alpha$ TC- 6 cells and hamster or mouse tissues (liver, kidney, skeletal muscle and adipose tissue) was reverse-transcribed into cDNA with $50 \mathrm{pmol}$ of Oligo(dT) $)_{17}, 20 \mathrm{mmol} / 1$ of dNTPs, $50 \mathrm{U}$ of RNase inhibitor and $12.5 \mathrm{U}$ of Avian Moloney virus-reverse transcriptase in reverse transcriptase buffer $(50 \mathrm{mmol} / 1$ Tris $\mathrm{pH} 8.3$, $50 \mathrm{mmol} / 1 \mathrm{KCl}, 8 \mathrm{mmol} / 1 \mathrm{MgCl}_{2}, 5 \mathrm{mmol} / \mathrm{l} \mathrm{DTT}$ ) at $42^{\circ} \mathrm{C}$ for $120 \mathrm{~min}$, heated to $98^{\circ} \mathrm{C}$ for $10 \mathrm{~min}$, and immediately chilled on ice. RT-PCR amplifications were carried out using one tenth of the total reverse transcription mixture, $100 \mathrm{pmol}$ of each primer, $2.5 \mathrm{mmol} / \mathrm{l}$ of dNTPs and $2.5 \mathrm{U}$ of Ampli Taq DNA polymerase $[17,18]$ in $100 \mu \mathrm{l}$ of reaction mixture containing PCR buffer $(10 \mathrm{mmol} / 1$ Tris $\mathrm{pH} 8.3,50 \mathrm{mmol} / \mathrm{l} \mathrm{KCl}$, 
$1.5 \mathrm{mmol} / 1 \mathrm{MgCl}_{2}, 0.001 \%$ gelatin) using a thermal cycle programmer (Model 300; Astec, Fukuoka, Japan) under conditions of denaturation at $94^{\circ} \mathrm{C}$ for $1 \mathrm{~min}$, annealing at $60^{\circ} \mathrm{C}$ for $1 \mathrm{~min}$, and extension at $72^{\circ} \mathrm{C}$ for $2 \mathrm{~min}$ for 30 cycles. The primers used for PCR reactions were designed from the common sequences between human and mouse insulin receptor $\mathrm{CDNA}$ [sense primer: 5'-CATCAAGGGTGAGGCAGAGA-3' residues 3273-3292 of human insulin receptor [16] (3135-3154, registered in the GenBank/EMBL Data Bank with accession number M10051) and 3105-3124 of mouse insulin receptor [19] (registered in the GenBank/EMBL Data Bank with accession number J05149); antisense primer: 5'-TTGGCCTCATCTTGGGGTTG-3' residues 3963-3982 of human insulin receptor [16] (3825-3844 GenBank/EMBL Data Bank) and 3795-3814 of mouse insulin receptor [19] (GenBank/ EMBL Data Bank)]. After amplification, the PCR products were subjected to $1 \%$ agarose gel electrophoresis, and extracted using a Gene Clean kit. The purified fragments were subcloned into the pUC 19 plasmids and sequenced by the dideoxynucleotide chain termination method with a Sequenase version 2.0 DNA sequencing kit and $\left[\alpha-{ }^{32} \mathrm{P}\right] \mathrm{dCTP}[20]$.

Immunocytochemical staining. In-R1-G9 or $\alpha \mathrm{TC}-6$ cells grown on Lab-Tek chamber slide (4-well) were fixed for $10 \mathrm{~min}$ in $100 \%$ acetone. After rinsing $3 \times 1$ min with PBS, coverslips were incubated in a blocking solution consisting of PBS with $1 \%$ BSA and $0.02 \%$ non-immune goat serum. After a further rinse with PBS, the cells were incubated overnight at $4{ }^{\circ} \mathrm{C}$ with a rabbit anti-insulin receptor $\alpha$-subunit antibody diluted at $1: 100$. The slides were rinsed with PBS, incubated with a donkey anti-rabbit Ig horseradish peroxidase linked $\mathrm{F}\left(\mathrm{ab}^{\prime}\right)_{2}$ fragment, and the reactions were developed using AEC solution $(0.02 \%$ AEC/DMSO, $0.0475 \mathrm{~mol} / \mathrm{l}$ acetate buffer $\mathrm{pH} 5.0$ and $0.006 \% \mathrm{H}_{2} \mathrm{O}_{2}$ ) as a chromogen. After a final rinse with PBS, the sections were briefly counterstained with haematoxylin and mounted with Aquatex.

${ }^{35}$ S]Methionine labelling of insulin receptor protein. Subconfluent In-R1-G9 or $\alpha$ TC- 6 cells were suspended in methionine-free medium at $37^{\circ} \mathrm{C}$ for $1 \mathrm{~h}$ followed by incubation with $\left[{ }^{35} \mathrm{~S}\right]$ methionine $(50 \mu \mathrm{Ci} / \mathrm{ml})$ at $37^{\circ} \mathrm{C}$ for $12 \mathrm{~h}$ [21]. After labelling, these cells were solubilized in lysis buffer $(50 \mathrm{mmol} / \mathrm{l}$ HEPES pH 7.5 containing $150 \mathrm{mmol} / 1 \mathrm{NaCl}, 1 \%$ Triton $\mathrm{X}-100,5 \mathrm{mmol} / \mathrm{l} \mathrm{EDTA}, 5 \mathrm{mmol} / \mathrm{E} \mathrm{EGTA}, 20 \mathrm{mmol} / \mathrm{l}$ sodium pyrophosphate, $1 \mathrm{mmol} / 1 \mathrm{PMSF}, 1 \mathrm{mmol} / 1$ sodium orthovanadate, $20 \mathrm{mmol} / \mathrm{l}$ sodium fluoride, $1 \mathrm{mg} / \mathrm{ml}$ Bacitracin), and sonicated. After centrifugation at $100,000 \times \mathrm{g}$ for $90 \mathrm{~min}$ at $4{ }^{\circ} \mathrm{C}$, the supernatants were incubated with anti-insulin receptor antibody (Ab-3) or non-immune serum as a control for $2 \mathrm{~h}$ at $4^{\circ} \mathrm{C}$. Immunoprecipitations were performed by addition of $40 \mu \mathrm{l}$ of protein G-Sepharose 4B. After $2 \mathrm{~h}$ of incubation at $4^{\circ} \mathrm{C}$, the suspensions were sedimented by centrifugation at $10,000 \times g$ for $5 \mathrm{~min}$ at $4^{\circ} \mathrm{C}$. The immunoprecipitates were solubilized in sample buffer $(62.5 \mathrm{mmol} / \mathrm{l}$ Tris-HCl pH $6.8 \mathrm{con}-$ taining $10 \%$ glycerol, $5 \%$ 2-mercaptoethanol, $2 \%$ SDS and $0.01 \%$ bromophenol blue) and heated in a boiling water bath for 5 min. Proteins were then separated by SDS PAGE ( $6 \%$ polyacrylamide gel electrophoresis) and autoradiography was performed.

Autophosphorylation of insulin receptor. In-R1-G9 or $\alpha$ TC-6 cells grown in a 100-mm dish were incubated with RPMI-1640 medium with $0.5 \%$ BSA and DMEM $(25 \mathrm{mmol} / 1$ glucose $)$ medium with $0.5 \%$ BSA with or without $10^{-6} \mathrm{~mol} / / \mathrm{insulin}$ at $37^{\circ} \mathrm{C}$ for $30 \mathrm{~min}$, respectively. Cells were washed with PBS, scraped in hypotonic buffer $(20 \mathrm{mmol} / 1$ Tris $\mathrm{pH} 7.5$ containing $5 \mathrm{mmol} / \mathrm{l} \mathrm{EDTA}, 0.1 \mathrm{mmol} / \mathrm{l}$ DTT, $20 \mu \mathrm{mol} / 1 \mathrm{PMSF}, 1 \mathrm{mg} / \mathrm{ml}$
Bacitracin), centrifuged at $500 \times g$ for $5 \min$ at $4{ }^{\circ} \mathrm{C}$, suspended in hypotonic buffer, and sonicated. After centrifugation of sonicates at $30,000 \times g$ for $5 \mathrm{~min}$ at $4{ }^{\circ} \mathrm{C}$, the supernatants were further centrifuged at $200,000 \times g$ for $20 \mathrm{~min}$ at $4^{\circ} \mathrm{C}$. Pellets were suspended in lysis buffer, sonicated, and then centrifuged at $200,000 \times \mathrm{g}$ for $20 \mathrm{~min}$ at $4^{\circ} \mathrm{C}$. The supernatants were adsorbed to microtitre wells previously coated with anti-insulin receptor antibody $(\mathrm{Ab}-3)$. Adsorbed insulin receptors were incubated with reaction mixture $(50 \mathrm{mmol} / 1 \mathrm{HEPES} \mathrm{pH} 7.5 \mathrm{con}-$ taining $150 \mathrm{mmol} / 1 \mathrm{NaCl}, 0.1 \%$ Triton X-100, $5 \mathrm{mmol} / 1 \mathrm{MgCl}_{2}$, $5 \mathrm{mmol} / / \mathrm{MnCl}_{2}$, and $10 \mu \mathrm{mol} / /\left[\gamma-{ }^{32} \mathrm{P}\right] \mathrm{ATP}(10-15 \mu \mathrm{Ci} / \mathrm{nmol})$ with or without $10^{-7} \mathrm{~mol} / \mathrm{l}$ insulin at $24^{\circ} \mathrm{C}$ for $10 \mathrm{~min}$ [6].

The reaction mixtures were solubilized in sample buffer and heated in a boiling water bath for $5 \mathrm{~min}$ and separated by SDS PAGE ( $6 \%$ polyacrylamide gel electrophoresis). The autoradiography was then performed.

\section{Assay and statistical analysis.}

Glucagon immunoreactivity in culture media was measured using OAL 123; Daiichi Radioisotope Institute (Tokyo, Japan) [22], the antibody specific for pancreatic glucagon.

Data are presented as mean \pm SEM. Statistical analysis was performed using the Student's $t$-test. Statistical significance was accepted with $p$-values less than $5 \%$.

\section{Results}

Effect of insulin on glucagon secretion in In-R1-G9 and $\alpha T C-6$ cells. To examine the effect of insulin on glucagon secretion in In-R1-G9 and $\alpha$ TC- 6 cells, secreted glucagon was measured by radioimmunoassay after the addition of various concentrations of insulin into the culture media. As shown in Figure 1A, glucagon secretion decreased significantly $(p<0.05)$ depending on the concentrations of insulin (In-R1G9 cells: $4.2 \pm 0.3,3.2 \pm 0.2,2.9 \pm 0.2,2.6 \pm 0.2$ and $2.4 \pm 0.2 \mathrm{ng} \cdot 10^{6}$ cells $^{-1} \cdot 2 \mathrm{~h}^{-1}$ at $0,10^{-12}, 10^{-10}, 10^{-8}$ and $10^{-6} \mathrm{~mol} / 1$ insulin; $\alpha \mathrm{TC}-6$ cells $14.8 \pm 0.9$, $11.9 \pm 0.5,10.8 \pm 0.5,9.6 \pm 0.4$ and $8.8 \pm 0.4 \mathrm{ng} \cdot 10^{6}$ cells $^{-1} \cdot 2 \mathrm{~h}$ at $0,10^{-12}, 10^{-10}, 10^{-8}$ and $10^{-6} \mathrm{~mol} / \mathrm{l}$ insulin, respectively). In the evaluation of the time course (Fig. 1B), glucagon secretion with $10^{-8} \mathrm{~mol} / 1$ insulin at 2, 6, 12 and $24 \mathrm{~h}$ was significantly $(p<0.05)$ lower than without insulin in both cells (In-R1-G9 cells: $2.6 \pm 0.2$ vs $4.2 \pm 0.3$ at $2 \mathrm{~h}, 3.6 \pm 0.6$ vs $6.0 \pm 0.7$ at $6 \mathrm{~h}, 4.5 \pm 0.8$ vs $8.1 \pm 1.3$ at $12 \mathrm{~h}$ and $6.3 \pm 1.3$ vs $12.2 \pm 2.1 \mathrm{ng} / 10^{6}$ cells at $24 \mathrm{~h}$; $\alpha \mathrm{TC}-6$ cells: $9.6 \pm 0.8$ vs $14.8 \pm 1.5$ at $2 \mathrm{~h}, 11.2 \pm 1.6$ vs $18.2 \pm 2.4$ at $6 \mathrm{~h}$, $16.0 \pm 2.5$ vs $27.7 \pm 3.9$ at $12 \mathrm{~h}$ and $22.2 \pm 3.5$ vs $41.2 \pm 5.0 \mathrm{ng} / 10^{6}$ cells at $24 \mathrm{~h}$, respectively). According to these data, insulin regulated the glucagon secretion negatively at the concentrations of $10^{-12}$ to $10^{-6} \mathrm{~mol} / \mathrm{l}$, and regulation was observed at 2 to $24 \mathrm{~h}$ of insulin stimulation.

Insulin binding to In-R1-G9 and $\alpha T C-6$ cells. To analyse the insulin receptor on the cell surface, insulin binding assay was performed in In-R1-G9 and $\alpha \mathrm{TC}$ 6 cells. The displacement curve of In-R1-G9 and $\alpha \mathrm{TC}-6$ cells is shown in Figure $2 \mathrm{~A}$. The concentra- 

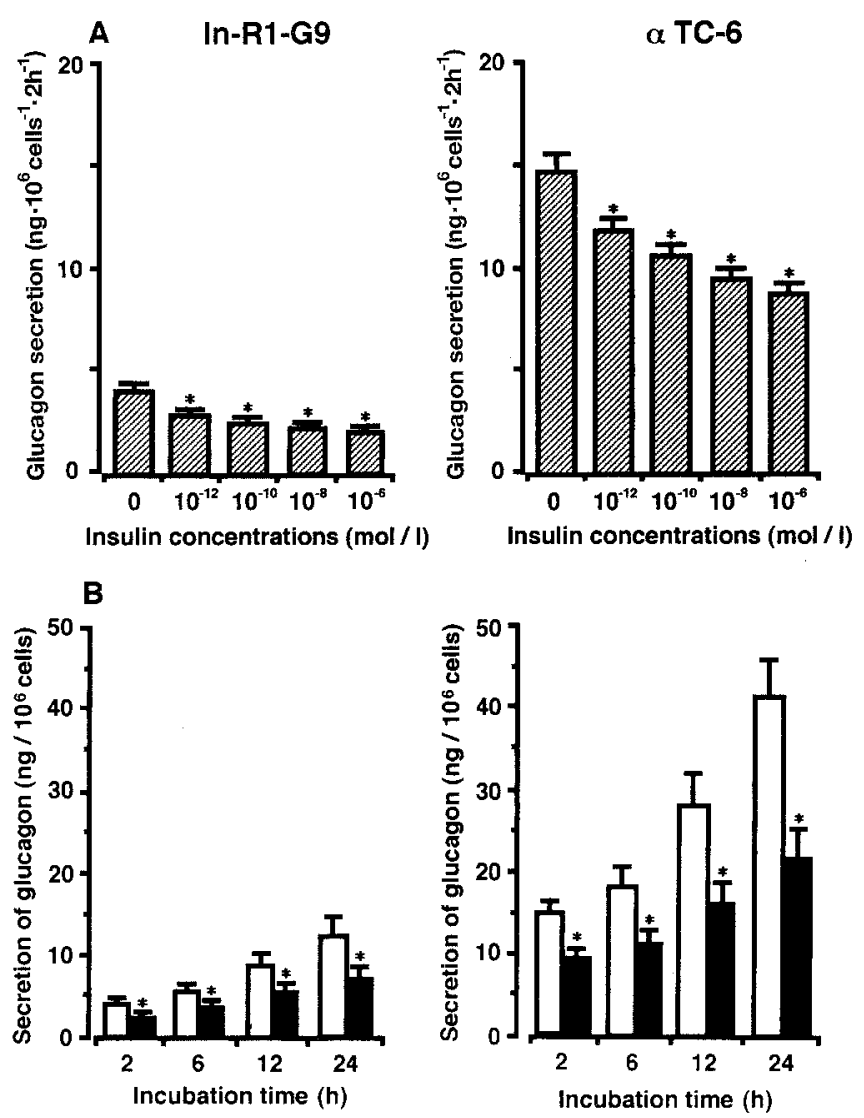

Fig. 1. (A, B) Effect of insulin on glucagon secretion in In-R1G9 and $\alpha$ TC- 6 cells. (A) Cells were incubated in the culture media with or without insulin at concentrations from $10^{-12}$ to $10^{-6} \mathrm{~mol} / 1$ for $2 \mathrm{~h} \mathrm{(G).} \mathrm{(B)} \mathrm{Cells} \mathrm{were} \mathrm{incubated} \mathrm{in} \mathrm{the} \mathrm{culture}$ media with ( $\boldsymbol{\square}$ ) or without ( $\square$ ) insulin $\left(10^{-8} \mathrm{~mol} / \mathrm{l}\right)$ for $2,6,12$ and $24 \mathrm{~h}$. Glucagon secreted in the medium was measured by radioimmunoassay. Assays were run in triplicate. Results represent the mean $\pm \operatorname{SEM}(n=6) . * p<0.05$
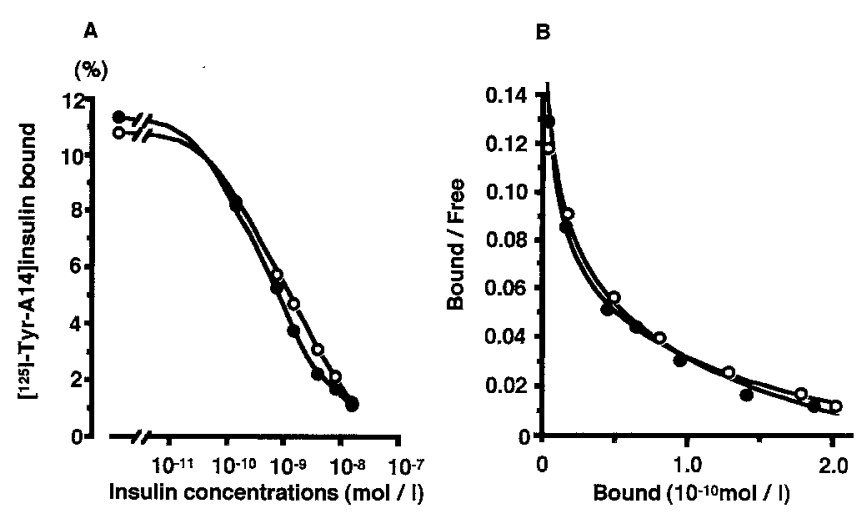

Fig. 2. (A, B) Insulin receptor binding assay in In-R1-G9 and $\alpha$ TC-6 cells. Cells were incubated with $\left[{ }^{125}\right.$ I-Tyr-A14]insulin and the indicated concentrations of unlabelled insulin for $16 \mathrm{~h}$ at $4{ }^{\circ} \mathrm{C}$. (A) Competition binding curve, with results expressed as percent of ${ }^{125}$ I-labelled insulin bound; In-R1-G9 cells (O), aTC-6 cells $(\bullet)$. (B) The same data transformed by the method of Scatchard. Means of duplicate determinations of one representative experiment are shown
A
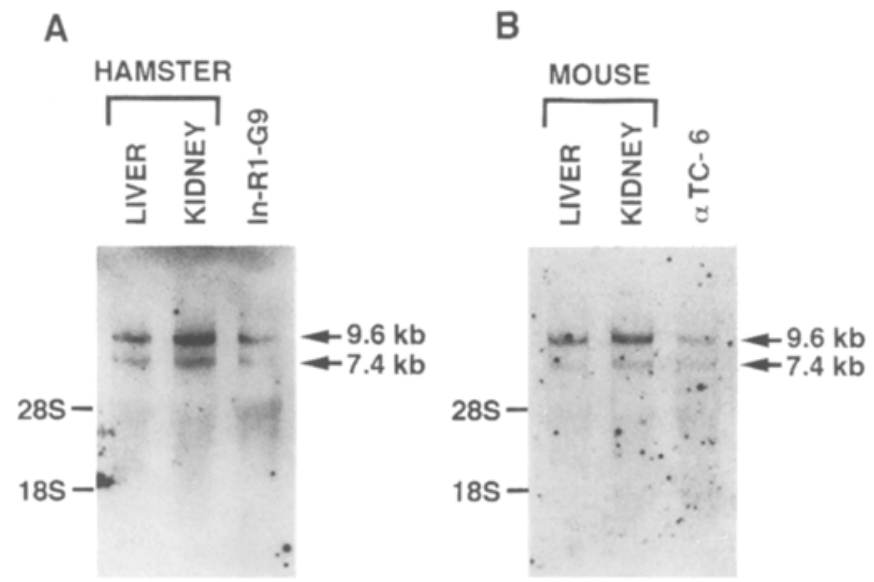

Fig. 3. (A, B) Expression of insulin receptor mRNA in In-R1G9 and $\alpha$ TC- 6 cells by Northern blot analysis. Poly(A) ${ }^{+}$RNAs were extracted from (A) hamster liver, kidney and In-R1-G9 cells, and from (B) mouse liver, kidney and $\alpha$ TC- 6 cells. Ten micrograms of Poly $(\mathrm{A})^{+}$RNA was electrophoresed in $1.0 \%$ agarose gel, transferred to nitrocellulose membranes, and hybridized with human insulin receptor cDNA probe. The positions of the $28 \mathrm{~S}$ and $18 \mathrm{~S}$ ribosomal RNA markers are indicated. 9.6 and $7.4 \mathrm{~kb}$ bands corresponding to insulin receptor mRNA are detected in both cells as well as hamster and mouse tissues

tions of unlabelled insulin required for half-maximal displacement of [ $\left.{ }^{125} \mathrm{I}-\mathrm{Tyr}-\mathrm{A} 14\right]$ insulin were 0.94 and $0.87 \mathrm{nmol} / 1$ in In-R1-G9 and $\alpha$ TC- 6 cells, respectively. Scatchard analysis revealed typical curvilinear plots for the insulin receptor (Fig. 2B). Affinity constants for high affinity site $\left(\mathrm{K}_{1}\right)$ and low affinity site $\left(\mathrm{K}_{2}\right)$ in In-R1-G9 cells were $2.1 \times 10^{9}$ and $6.2 \times 10^{7} \mathrm{~mol} / \mathrm{l}^{-1}$, respectively, and binding sites for high affinity site $\left(R_{1}\right)$ and low affinity site $\left(R_{2}\right)$ were $0.27 \times 10^{4}$ and $1.86 \times 10^{4}$ sites/cell, respectively. In $\alpha \mathrm{TC}-6$ cells, $\mathrm{K}_{1}$ and $\mathrm{K}_{2}$ were $2.1 \times 10^{9}$ and $7.3 \times 10^{7} \mathrm{~mol} / /^{-1}$, respectively, and $R_{1}$ and $R_{2}$ were $0.27 \times 10^{4}$ and $1.95 \times 10^{4}$ sites/cell, respectively.

Expression of insulin receptor $m R N A$ in $I n-R 1-G 9$ and $\alpha T C-6$ cells. To detect the existence of insulin receptor mRNA in In-R1-G9 and $\alpha$ TC- 6 cells, Northern blot analysis and RT-PCR analysis of insulin receptor mRNA were performed.

In the Northern blot analysis using the human insulin receptor cDNA as a probe, two major bands of insulin receptor mRNA (9.6- and 7.4-kilobase (kb)), were detected in both cells, as well as in hamster or mouse liver and kidney (Fig. 3).

In RT-PCR analysis, a predicted size (710 basepair (bp) ) DNA fragment was amplified in both cells (Fig.4). By sequence analysis, this $710 \mathrm{bp}$ fragment was shown to be identical to the insulin receptor cDNA sequence (data not shown).

Expression of insulin receptor protein in In-R1-G9 and $\alpha T C-6$ cells. To find the expression of insulin re- 
A

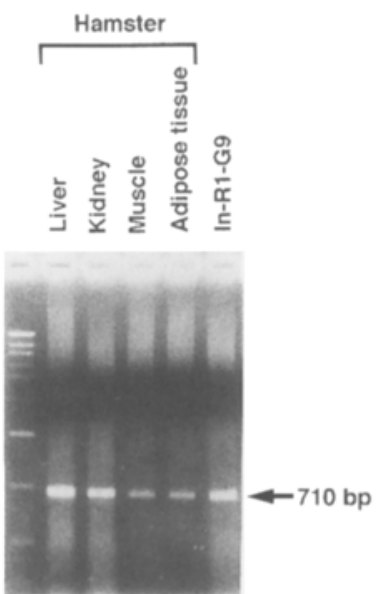

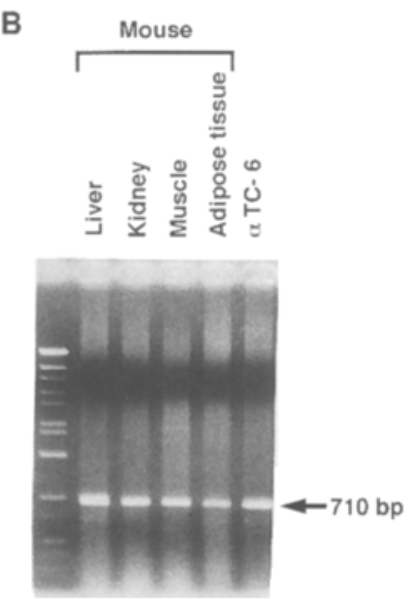

Fig. 4. (A, B) Detection of insulin receptor mRNA by RTPCR method in In-R1-G9 and $\alpha$ TC-6 cells. Total RNAs were prepared from both cells and rodent tissues - (A) hamster liver, kidney, skeletal muscle, adipose tissue and In-R1-G9 cells, (B) mouse liver, kidney, skeletal muscle, adipose tissue and $\alpha$ TC -6 cells, and reverse-transcribed into cDNA using oligo dT primer. PCR amplifications were carried out with a pair of primers designed from insulin receptor gene cDNA, and PCR products were subjected to $1.0 \%$ agarose gel electrophoresis. The anticipated size of a $710 \mathrm{bp}$ DNA fragment is observed from both cells as well as hamster and mouse tissues

ceptor protein in In-R1-G9 and $\alpha$ TC- 6 cells, immunocytochemical staining and $\left.{ }^{35} \mathrm{~S}\right]$ methionine labelling of the insulin receptor was performed.

As shown in Figure 5, positive immunostaining for insulin receptors was observed in both cells by using an anti-insulin receptor $\alpha$-subunit antibody. Replacement of the primary antibody with non-immune rabbit IgG showed no immunostaining in both cells. Furthermore, preincubation with porcine insulin before incubating with anti-insulin receptor $\alpha$-subunit antibody resulted in the abolition of positive immunostaining in both cells.

$\left[{ }^{35} \mathrm{~S}\right]$ Methionine labelling of partially purified insulin receptors in both cells is shown in Figure 6. Two major bands of $M_{r} 135,000$ and $M_{r} 95,000$ corresponding to the $\alpha$ and $\beta$ subunit of the insulin receptor were observed in both In-R1-G9 and $\alpha$ TC- 6 cells. In addition, another major band $\left(M_{r} 210,000\right)$ which seemed to be a precursor of the insulin receptor was also recognized in In-R1-G9 cells.

Insulin-stimulated autophosphorylation of the insulin receptor $\beta$-subunit in In-RI-G9 and $\alpha$ TC- 6 cells. To examine the insulin-stimulated phosphorylation of the insulin receptor expressed in In-R1-G9 and $\alpha \mathrm{TC}-6$ cells, autophosphorylation reactions were performed using the partially purified insulin receptors prepared from both cells. An $\mathrm{M}_{\mathrm{r}} 95,000$ band corresponding to the phosphorylated $\beta$-subunit of the insulin receptor was observed only in the presence of insulin $\left(10^{-7}\right.$ mol/1) in In-R1-G9 and $\alpha$ TC-6 cells (Fig. 7).

A

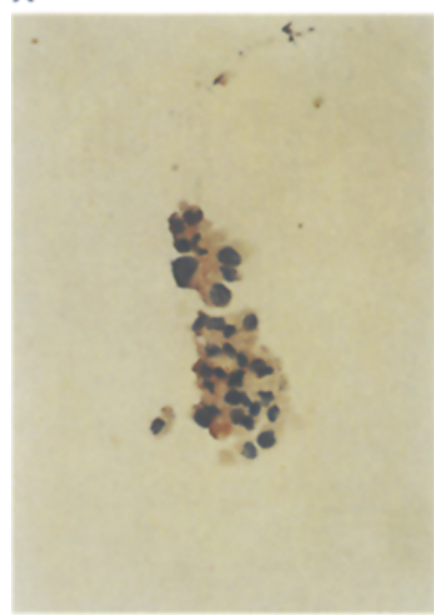

B

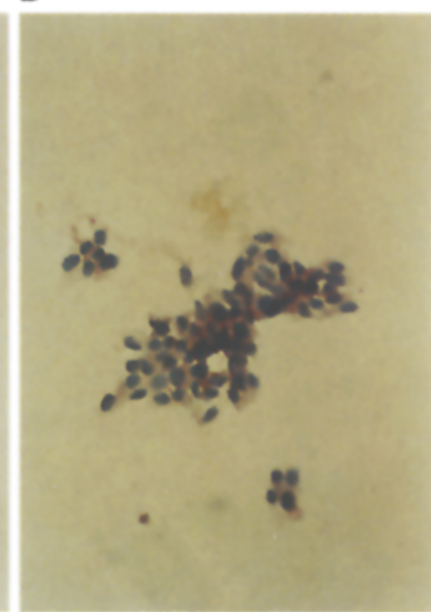

Fig. 5. (A, B) Immunocytochemical staining of insulin recep tor on In-R1-G9 and $\alpha$ TC-6 cells. Cells were prepared for immunocytochemical staining of insulin receptor as described in Materials and Methods. Positive staining with anti-insulin receptor $\alpha$-subunit antibody are observed in (A) In-R1-G9 cells and (B) $\alpha$ TC- 6 cells. Magnification: $\times 200$

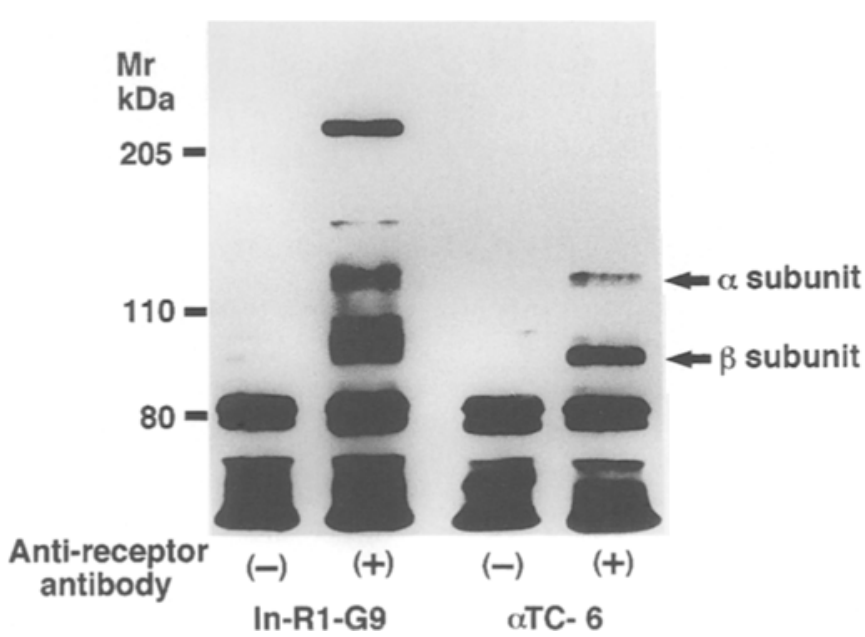

Fig. 6. SDS-PAGE of $\left.{ }^{35} \mathrm{~S}\right]$ methionine-labelled insulin receptor subunits in In-R1-G9 and $\alpha$ TC-6 cells. Lysates of the cells were immunoprecipitated with anti-insulin receptor antibody $(A b-3)(+)$ or control non-immune serum $(-)$, separated by SDS-PAGE (6\% polyacrylamide gel electrophoresis) and analysed by autoradiography. Molecular weight markers are indicated on the left. Two major bands of $M_{r} 135,000$ and $M_{r}$ 95,000 corresponding to the $\alpha$ and $\beta$ subunits of insulin receptor are observed in both cells, and a band of $\mathrm{M}_{\mathrm{r}} 210,000$ corresponding to a precursor of the insulin receptor is recognized only in In-R1-G9 cells

\section{Discussion}

In previous experiments using isolated pancreatic alpha cells $[7,8]$, no definite conclusion was reached regarding the existence of an insulin receptor on the alpha cells, probably due to the difficulty in obtaining a large enough number of isolated pancreatic alpha cells to detect the insulin receptor, or the contamina- 


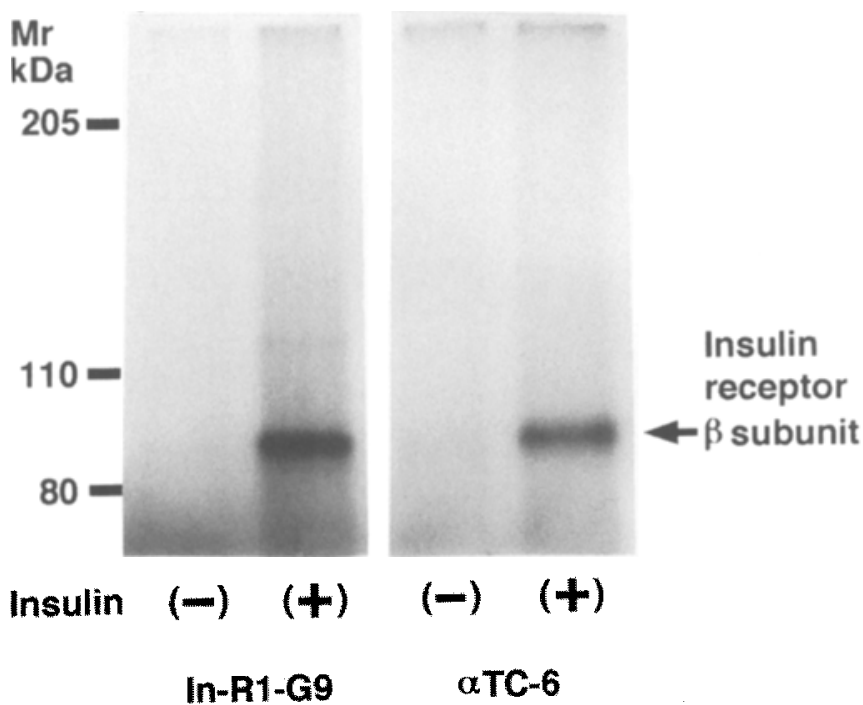

Fig. 7. Insulin-stimulated autophosphorylation of insulin receptor $\beta$ subunit in In-R1-G9 and $\alpha$ TC- 6 cells. Purified receptors were adsorbed to microtitre wells previously coated with anti-insulin receptor antibody (Ab-3), incubated with $[\gamma$ ${ }^{32} \mathrm{P}$ ]ATP in the presence or absence of $10^{-7} \mathrm{~mol} / \mathrm{l}$ insulin, and analysed by SDS-PAGE (6\% polyacrylamide gel electrophoresis) followed by autoradiography. Molecular weight markers are indicated on the left. In the presence of insulin, a band of $\mathrm{M}_{\mathrm{r}} 95,000$ corresponding to $\beta$ subunit of insulin receptor is observed in both cells

tion with other pancreatic cells (beta or delta) in pancreatic alpha-cell-rich cultures. In this report, we successfully demonstrate the expression of insulin receptor mRNA and protein, and insulin-stimulated autophosphorylation of the insulin receptor in two independent, established glucagon secreting cell lines; In-R1-G9 and $\alpha$ TC- 6 cells.

In-R1-G9 and $\alpha \mathrm{TC}-6$ cells do secrete glucagon, and do not produce insulin at levels detectable by radioimmunoassay. Also, in these cell lines, glucagon secretion by the stimulation of arginine $\left(10^{-2} \mathrm{~mol} / \mathrm{l}\right)$ and epinephrine $\left(10^{-6} \mathrm{~mol} / \mathrm{l}\right)$ was increased, and the increment by the stimulation of arginine $\left(10^{-2} \mathrm{~mol} / \mathrm{l}\right)$ was suppressed by additional insulin stimulation (data not shown). These results are consistent with previous reports on the effect of arginine or epinephrine on glucagon secretion in glucagon-secreting cell lines or isolated pancreatic alpha cells $[9,23$, $24]$. From these data, we confirm that the cell lines used in our experiments show characteristics of native islet alpha cells. Furthermore, the cell lines did not contain pancreatic delta cells; no detectable somatostatin mRNA and negative immunocytochemical staining for somatostatin were observed, as reported previously $[10,25]$. These glucagon cell lines, therefore, allowed us to obtain material homogeneous and intact enough to study the regulation of glucagon secretion from pancreatic alpha cells.

We found the decrease in glucagon secretion caused by insulin treatment in the range of $10^{-12}$ to
$10^{-6} \mathrm{~mol} / \mathrm{l}$. The concentrations of insulin released into the core capillaries of pancreatic islets have been reported to be in the range of $10^{-9}$ to $10^{-7} \mathrm{~mol} / \mathrm{l}$ [26]. Therefore, glucagon secretion from normal islet alpha cells in vivo is considered to be regulated by insulin at concentrations of more than $10^{-9} \mathrm{~mol} / 1$. In our study, glucagon secretion decreased even at insulin concentrations under $10^{-9} \mathrm{~mol} / \mathrm{l}$. Our results are concordant with those of Phillipe [27] and Takaki et al. [9] who studied the regulation of glucagon secretion by insulin in In-R1-G9 cells. It is not quite clear why these clonal alpha cells in vitro show high sensitivity to insulin compared with intra-islet alpha cells in vivo. Phillipe [27] suggested that the number and/ or the affinity of the insulin receptor on intra-islet alpha cells might decrease by chronic exposure to the high concentrations of insulin secreted from beta cells compared with clonal alpha cells. This might account for the difference in insulin sensitivity between clonal alpha cells and intra-islet alpha cells.

Analysis of the receptor binding assay showed the estimated number of insulin receptors to be approximately $2.0 \times 10^{4}$ receptors per cell for both In-R1-G9 and $\alpha$ TC- 6 cells, which was comparable with that of rat adipocytes and human fibroblasts $\left(\sim 5 \times 10^{4} /\right.$ cell and $-1.3 \times 10^{4} /$ cell, respectively) $[28,29]$. However, these were lower than those reported for human adipocytes and higher than those of human erythrocytes $[30,31]$. In a previous report, Van Schravendijk et al. [8] did not find a significant number of high-affinity insulin receptors in isolated pancreatic alpha cells (400 sites per cell), which were 50 - to 500 -fold lower than in classic insulin target cells. The difference between our results and theirs might result from the differences of cell species. Our Scatchard analysis also revealed that the affinity constants for the high affinity site $\left(\mathrm{K}_{1}\right)$ and low affinity site $\left(\mathrm{K}_{2}\right)$ in In-R1-G9 and $\alpha$ TC- 6 cells (In-R1-G9: $\mathrm{K}_{1}=2.1 \times 10^{9} \mathrm{~mol} / \mathrm{l}^{-1}$, $\mathrm{K}_{2}=6.2 \times 10^{7} \mathrm{~mol} / \mathrm{l}^{-1} ; \quad \alpha \mathrm{TC}$ clone $6: \quad \mathrm{K}_{1}=2.1 \times$ $10^{9} \mathrm{~mol} / \mathrm{l}^{-1}, \quad \mathrm{~K}_{2}=7.3 \times 10^{7} \mathrm{~mol} / \mathrm{l}^{-1}, \quad$ respectively), which were similar to those of fibroblasts or adipocytes $\left(\mathrm{K}_{1}=10^{9}-10^{10} \mathrm{~mol} / \mathrm{l}^{-1}, \quad \mathrm{~K}_{2}=10^{7}-10^{8} \mathrm{~mol} / \mathrm{l}^{-1}\right)$ [28-31]. From these receptor binding assay results, it was presumed that insulin receptors of these cells could function like those of insulin target cells.

We found 9.6 and $7.4 \mathrm{~kb}$ mRNAs specific for the insulin receptor in both In-R1-G9 and $\alpha$ TC- 6 cells. These mRNAs seemed to be identical with two predominant insulin receptor mRNAs found in rodent tissues (liver, kidney, brain and muscle) [32]. The presence of insulin receptor mRNA was also confirmed by RT-PCR methods using a pair of primers (the sense and anti-sense primers) complementary to the cDNA of the insulin receptor gene. As a result, as expected a size $710 \mathrm{bp}$ DNA fragment was obtained from both clonal cells, and hamster and mouse tissues. Furthermore, we determined the nucleotide sequence of this $710 \mathrm{bp}$ DNA fragment 
which was found to be identical to that of the insulin receptors and different from that of the IGF-1 receptors [33]. From these results, we deduced the existence of insulin receptor mRNA in In-R1-G9 and $\alpha$ TC- 6 cells.

Insulin receptor protein in In-R1-G9 and $\alpha \mathrm{TC}-6$ cells was demonstrated both by immunocytochemical staining and by ${ }^{35}$ S $]$ methionine labelling. By $\left[{ }^{35} \mathrm{~S}\right]$ methionine labelling of insulin receptor protein, we found two major bands of $M_{r} 135,000$ and $\mathrm{M}_{\mathrm{r}} 95,000$ corresponding to the $\alpha$ and $\beta$ subunit of the insulin receptor in both cells. In addition, a band of $\mathrm{M}_{\mathrm{r}}$ 210,000 was detected in In-R1-G9 cells but not in $\alpha$ TC-6 cells. This $M_{r} 210,000$ protein is known to be a precursor of the insulin receptor subunits, which is partially expressed in the plasma membrane [21, 34]. The receptor precursor shows little binding to the insulin and its turnover rate is faster (the halflife: 7-9 h) compared with mature insulin receptor (the half-life: 9-12 h) [21, 34]. Cleavage of insulin proreceptor into $\alpha$ and $\beta$ subunit is considered to be catalysed by the cellular endoprotease; furin $[35,36]$. Yanagita et al. [37] reported that the expression of furin varied among the cell lines. Therefore, we presume that the difference of expression of this $M_{r}$ 210,000 subunit between In-R1-G9 cells and $\alpha$ TC- 6 cells might be due to the difference in furin expression.

We showed insulin-stimulated phosphorylation of the insulin receptor $\beta$-subunit expressed in In-R1G9 and $\alpha$ TC- 6 cells. The phosphorylation of the insulin receptor $\beta$-subunit is known to be an important step for insulin-mediated signal transduction of insulin $[5,6]$. Therefore, we conclude that the function of insulin receptors expressed in In-R1-G9 and aTC-6 cells is to mediate insulin signals into the cells.

It has been reported that not only insulin but also IGF-1 can decrease glucagon secretion from pancreatic alpha cells [38], suggesting the existence of IGF-1 receptors on pancreatic alpha cells. Since insulin is also known to bind to IGF-1 receptors, we could not neglect the possible involvement of the IGF-1 receptors on insulin-induced suppression of glucagon secretion in these cells. Further studies are necessary to clarify the role of these two receptors on glucagon secretion.

The exact molecular mechanism of regulation of glucagon secretion by insulin has not yet been elucidated. It is conceivable that the suppression of glucagon secretion by insulin is caused by the inhibition of post-transcriptional process and/or the reduced biosynthesis of glucagon. Philippe [27, 39] reported that the glucagon gene expression was negatively regulated by insulin at the transcriptional level through an insulin-responsive DNA element of the glucagon gene promoter in In-R1-G9 cells. However, further studies including the insulin receptor signalling pathway are necessary to elucidate the exact molecular mechanism of negative glucagon secretion regulated by insulin.

In conclusion, our study showed that the significant numbers of insulin receptors were correctly synthesized and expressed on clonal pancreatic alpha cells, In-R1-G9 and $\alpha$ TC- 6 cells, and may regulate insulin-stimulated negative regulation of glucagon secretion of both cells. These findings suggest that the regulation of insulin on pancreatic alpha cells may be mediated by specific cell-surface insulin receptors.

Acknowledgements. We thank Dr. R. Takaki and Dr. K. Hamaguchi (The First Department of Medicine, Medical College of Oita) for supplying the In-R1-G9 cells and $\alpha \mathrm{TC}$ clone 6 cells, Dr. M. Takeya (The Second Department of Pathology, Kumamoto University School of Medicine) for assistance with the immunocytochemistry, and Dr. Y.Ebina (The Department of Enzyme Genetics, Institute for Enzyme Research, The University of Tokushima) for human insulin receptor cDNA.

This work was supported in part by a grant-in-aid for scientific research from the Ministry of Education., Science and $\mathrm{Cul}-$ ture of Japan (No. 06671043) and a grant for diabetic research from Otsuka Pharmaceutical Co., Ltd. (EA).

\section{References}

1. Shichiri M, Kawamori R, Abe H (1979) Normalization of the paradoxic secretion of glucagon in diabetics who were controlled by the artificial beta cell. Diabetes $28: 272-275$

2. Kawamori R, Shichiri M, Kikuchi M, Yamasaki Y, Abe H (1980) Perfect normalization of excessive glucagon responses to intravenous arginine in human diabetes mellitus with the artificial beta cell. Diabetes 29: 762-765

3. Paolisso G, Sgambato S, Torella R, Varricchio M, Scheen A, D'Onoerio F, Lefebvre PJ (1988) Pulsatile insulin delivery is more efficient than continuous infusion in modulating islet cell function in normal subjects and patients with type 1 diabetes. J Clin Endocrinol Metab 66: 1220-1226

4. Hamaguchi T, Fukushima H, Uehara M et al. (1991) Abnormal glucagon response to arginine and normalization in obese hyperinsulinaemic patients with glucose intolerance: importance of insulin action on pancreatic alpha cells. Diabetologia 34: 801-806

5. Kahn CR, White MF (1988) The insulin receptor and the molecular mechanism of insulin action. J Clin Invest 82 : $1151-1156$

6. Ebina Y, Araki E, Taira M et al. (1987) Replacement of lysine residue 1030 in the putative ATP-binding region of the insulin receptor abolishes insulin- and antibody-stimulated glucose uptake and receptor kinase activity. Proc Natl Acad Sci USA 84: 704-708

7. Patel YC (1982) Quantitative electron microscopic autoradiography of insulin, glucagon, and somatostatin binding sites on islets. Science 217: 1155-1156

8. Van Schravendijk CFH, Foriers A, Hooghe-Peters El et al. (1985) Pancreatic hormone receptors on islet cells. Endocrinology 117: 841-848

9. Takaki R, Ono J, Nakamura M et al. (1986) Isolation of glucagon-secreting cell lines by cloning insulinoma cells. In Vitro Cell Dev Biol 22: 120-126

10. Hamaguchi K, Leiter EH (1989) Comparison of cytokine effects on mouse pancreatic $\alpha$-cell and $\beta$-cell lines. Viabili- 
ty, secretory function, and MHC antigen expression. Diabetes 39: $415-425$

11. Powers AC, Efrat S, Mojsov S, Spector D, Habener JF, Hanahan D (1989) Proglucagon processing similar to normal islets in pancreatic $\alpha$-like cell line derived from transgenic mouse tumor. Diabetes 39: 406-414

12. Scatchard G (1949) The attractions of proteins for small molecules and ions. Ann N Y Acad Sci 51: 660-672

13. Thakur AK, Jaffe ML, Rodbard D (1980) Graphical analysis of ligand-binding systems: evaluation by Monte Carlo studies. Anal Biochem 107: 279-295

14. Rosenthal HE (1967) A graphic method for the determination and presentation of binding parameters in a complex system. Anal Biochem 20: 525-532

15. Chirgwin JM, Przybyla AE, MacDonald RJ, Rutter WJ (1979) Isolation of biologically active ribonucleic acid from sources enriched in ribonuclease. Biochemistry 18: 5294-5299

16. Ebina Y, Ellis L, Jarnagin K et al. (1985) The human insulin receptor cDNA: the structural basis for hormone-activated transmémbrane signalling. Cell 40: 747-758

17. Saiki RK, Scharf SJ, Faloona F et al. (1985) Enzymatic amplification of $\beta$-globin genomic sequences and restriction site analysis for diagnosis of sickle cell anemia. Science 230: $1350-1354$

18. Saiki RK, Gelfand DH, Stoffel S et al. (1988) Primer-directed enzymatic amplification of DNA with a thermostable DNA polymerase. Science 239: 487-489

19. Flores-Riveros JR, Sibley E, Kastelic T, Lane MD (1989) Substrate phosphorylation catalyzed by the insulin receptor tyrosine kinase: kinetic correlation to autophosphorylation of specific sites in the $\beta$ subunit. $\mathbf{J}$ Biol Chem 264: 21557-21572

20. Sanger F, Nicklen S, Coulson AR (1977) DNA sequencing with chain terminating inhibitors. Proc Natl Acad Sci USA 74: 5463-5467

21. Kasuga M, Hedo JA, Yamada KM, Kahn CR (1982) The structure of insulin receptor and its subunits. Evidence for multiple nonreduced forms and a 210,000 possible proreceptor. J Biol Chem 257: 10392-10399

22. Nishino T, Kodaira T, Shin et al. (1981) Glucagon immunoassay with use of antiserum to glucagon C-terminal fragment. Clin Chem 27: 1690-1697

23. Shennan KIJ, Holst JJ, Docherty K (1989) Proglucagon expression, posttranslational processing and secretion in SV40-transformed islet cells. Mol Cell Endocrinol 67: 9399

24. Pipeleers DG, Schuit FC, Van Schravendijk CFH, Van De Winkel M (1985) Interplay of nutrients and hormones in the regulation of glucagon release. Endocrinology 117: $817-823$
25. Drucker DJ, Philippe J, Mojsov S (1988) Proglucagon gene expression and post-translational processing in a hamster islet cell line. Endocrinology 123: 1861-1867

26. Samols E, Bonner-Weir S, Weir GC (1986) Intra-islet insulin-glucagon-somatostatin relationships. Clin Endocrinol Metab 15: 33-58

27. Philippe $\mathbf{J}$ (1989) Glucagon gene transcription is negatively regulated by insulin in a hamster islet cell line. J Clin Invest 84: $672-677$

28. Gammeltoft S, Gliemann $\mathbf{J}$ (1973) Binding and degradation of ${ }^{125}$ I-labelled insulin by isolated rat fat cells. Biochim Biophys Acta 320: 16-32

29. Hidaka H, Howard BV, Ishibashi F et al. (1981) Effect of $\mathrm{pH}$ and 3-hydroxybutyrate on insulin binding and action in cultured human fibroblasts. Diabetes 30: 402-406

30. Olefsky JM, Jen P, Reaven GM, Alto P (1974) Insulin binding to isolated human adipocytes. Diabetes 23: 565-571

31. Gavin III JR, Roth J, Jen P, Freychet P (1972) Insulin receptors in human circulating cells and fibroblasts. Proc Natl Acad Sci USA 69: 747-751

32. Goldstein BJ, Muller-Wieland D, Kahn CR (1987) Variation in insulin receptor messenger ribonucleic acid expression in human and rodent tissues. Mol Endocrinol 11: 759766

33. Ullrich A, Gray A, Tam AW et al. (1986) Insulin-like growth factor I receptor primary structure: comparison with insulin receptor suggests structural determinants that define functional specificity. EMBO Journal 5: 2503-2512

34. Hedo JA, Kahn CR, Hayashi M, Yamada KM, Kasuga M (1983) Biosynthesis and glycosylation of the insulin receptor. Evidence for a single polypeptide precursor of the two major subunits. J Biol Chem 258: 10020-10026

35. Barr PJ (1991) Mammalian subtilisins: the long-sought dibasic processing endoproteases. Cell 66: 1-3

36. Robertson BJ, Moehring JM, Moehring TJ (1993) Defective processing of the insulin receptor in an endoproteasedeficient Chinese hamster cell strain is corrected by expression of mouse furin. J Biol Chem 268: 24274-24277

37. Yanagita M, Hoshino H, Nakayama K, Takeuchi T (1993) Processing of mutated proinsulin with tetrabasic cleavage site to mature insulin reflects the expression of furin in nonendocrine cell lines. Endocrinology 133: 639-644

38. Boulware SD, Tamborlane WV, Rennert NJ, Gesundheit N, Sherwin RS (1994) Comparison of the metabolic effects of recombinant human insulin-like growth factor-1 and insulin: dose-response relationships in healthy young and middle-aged adults. J Clin Invest 93: 1131-1139

39. Philippe $J$ (1991) Insulin regulation of the glucagon gene is mediated by an insulin-responsive DNA element. Proc Natl Acad Sci USA 88: 7224-7227 